\title{
凍結豚肉より分離した低温発育細菌の発育温度特性
}

(昭和 48 年 12 月 18 日受理)

$$
\text { 小 久 保 弥 太 郎* }
$$

\section{Influence of Incubation Temperature on the Growth of Psychrotrophic Bacteria Isolated from Frozen Pork}

\author{
Yataro KoKUBo \\ (Department of Food Hygiene and Nutrition, Tokyo Metropolitan Reseach Laboratory \\ of Public Health: 24-1, 3-chome, Hyakunincho, Shinjuku-ku, Tokyo)
}

Growth temperature characteristics of 10 strains of psychrotrophic bacteria, which consisted of each 2 strains of Pseudomonas sp. (fluorescent type), Pseudomonas sp. (nonfluorescent type), Flavobacterium sp., Coryneforms sp. and Micrococcus sp., isolated from frozen pork were studied, since these 5 strains had been the most predominant contaminants of the frozen meat. Growth curves obtained on the 10 strains at varying temperatures covering 0 to $50^{\circ} \mathrm{C}$ with $5^{\circ} \mathrm{C}$ intervals were compared with those of 8 reference strains of stock cultures, Pseudomonas fluorescens, Pseudomonas fragi, Flavobacterium suaveolens, Cytophaga (Guppy B), Escherichia coli, Microbacterium thermosphactum, Micrococcus caseolyticus and Staphylococcus aureus. A temperature gradient incubator model TN-3 of Toyo Kagaku Sangyo Co. was used in this experiment.

Regardless of the genera of the organisms minimum temperatures for the growth of all the isolates tested were below $0^{\circ} \mathrm{C}$ and the optimum ones were 25 or $30^{\circ} \mathrm{C}$. The minimum generation time of the isolates varied from 29 to $65 \mathrm{~min}$. Among these isolates, both Pseudomonas fluorescent types and non-fluorescent ones showed maximum growth temperatures of 35 and $40^{\circ} \mathrm{C}$ respectively, while those of the other organisms were $30^{\circ} \mathrm{C}$. The growth rates of the psychrotrophic stock strains at $0^{\circ} \mathrm{C}$ were a little lower than those of the Pseudomonas sp. of the isolates.

(Received December 18, 1973)

著者はさきに，我が国に拈ける食肉需要のほぼなかば を占めるとみられる豚肉を対象に, 凍結および未凍結生 肉の細菌污染の実態ならびにそれらを低温貯蔵した場合 の污染細菌の挙動などに関する一連の調查を実施し，污 染細菌の中でも特に低温発育細菌が肉質の劣化に主働的 役割を演じ，品質管理上重要視すべき存在であることを 報告した ${ }^{1) \sim 3)}$.

低温発育細菌の食品衛生学的意義を考学るとさ，低温 発育細菌の実態ならびに概念を明確にすることが，これ らに対する品質管理面での対策を樹立する上からも必要 なことと思われる。 そのためにはまず基礎資料として, これらの細菌の生物学的特性を詳細に検討することが望

* 東京都立衛生研究所生活科学部乳肉衛生研究科：東 京都新宿区百人町 $3-24-1$
まれなかでも低温発育細菌の発育温度特性を知ること は最も基本的かつ重要とみなければならない。

これまで著者は低温発育細菌の発育温度特性につい て，それぞれいくつかの温度を設定し，各温度に拈ける 発育を観察してきた ${ }^{11,2)}$.

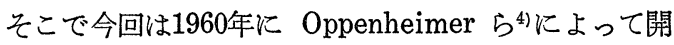
発された温度こう配培養法 (temperature gradient incubation method）を採用し，凍結豚肉より分離した 数種の低温発育細菌と既知の低温発育細菌, ならびに中 温細菌とみなされている Escherichia coli, Staphylococcus aureus などを対象に，0から50²及ぶ幅広い 温度域にわたって発育状態を観察し, これら菌株の発育 温度特性を比較検討した結果, 二, 三の知見を得たので 報告する。 


\section{実験方法}

\section{1. 供試菌株}

凍結豚肉分離菌株 として，数例の凍結豚カット肉 から 0 拈よび $25^{\circ}$ 培養に拈いて高い頻度で分離され， Vanderzant らの分類法 ${ }^{5}$ により属段階まで同定された 菌株のらちから, けい光のある Pseudomonas sp. とけ い光のない Pseudomonas sp., Flavobacterium sp., Coryneforms sp., Micrococcus sp. の5 種類について 各種類 2 株ずつ計 10 菌株を供試した。

な抏，上記各菌株と比較のために用いた保 存菌株は Pseudomonas fluorescens IAM 12022, Pseudomonas fragi IAM 1650, Flavobacterium suaveolens OUT 3752, Micrococcus caseolyticus OUT 8088, 味の素中 央研究所より分与された Cytophaga (Guppy B) およ び当研究所で冷蔵牛肉より分離された Microbacterium thermosphactum の 6 菌株ならびに豚生肉由来の Escherichia coli I 型株と Staphylococcus aureus $209 \mathrm{P}$ の計 8 菌株である.

\section{2. 培養方法}

1) 装置の設定

装置は東洋科学産業株式会社製の振とら温度こう配培 養装置 TN-3 型を使用した。設定温度域は. 0 から $5^{\circ}$ 間 隔で $50^{\circ}$ ま゙の11段階とし，各断続培養管挿入部に培湌 管を挿入し，毎分42回の振とうを行い，96時間まで培養 を継続した.なお，各段階での温度誤差は最大士0.5で あった。

2) 使用培地と培養操作
発育試験用培地は酵母エキスを $0.1 \%$ に添加したハー トインヒュージョンブイヨン培地（栄研化学製）を使用

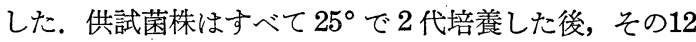
時間培湌菌液を滅菌生理食塩水で $1 \mathrm{ml}$ 当たり $10^{4} \sim 10^{5}$ 個の菌量になるように希釈し，その $1 \mathrm{ml}$ を各培養管に 移殖した。なお，各培養管はあらかじめ培地 $13 \mathrm{ml}$ を 分注滅菌し，菌接種にさきだち各こう配温度に 2 時間以 上保持したものを用いた。

\section{3. 菌数の測定}

最初の 24 時間は原則として 4 時間ごとに，その後は 12 時間ごとに各こう配温度の培養管から培養液 $0.1 \mathrm{ml}$ つを採取し, 滅菌生理食塩水で10進希䣋を行い, その $0.1 \mathrm{ml}$ を0.1\%酵母ェキス加ハートインヒュージョン寒 天培地 (栄研化学製) 平板に塗抹し，25で 48 時間培養 後発生した集落数から各こう配温度における菌数を算定 した.

\section{4. 発育温度特性の決定}

最低発育温度は96時間以内に発育の認められた最も低 い温度とし, $0^{\circ}$ で発育の認められたものは一応 $0^{\circ}$ とみな した。同様に，最高発育温度は発育の認められた最も高 い温度とした．至適発育温度は対数増殖期の世代時間が 最も短かく，乙かも最高生菌数に達した温度とした。な お，世代時間は Topley \& Wilson の方式にによって算出 した。

\section{実 験 結 果}

\section{1. 凍結豚肉分離菌株の発育温度特性}

各種類 1 株ずつについて，それぞれの主要温度におけ
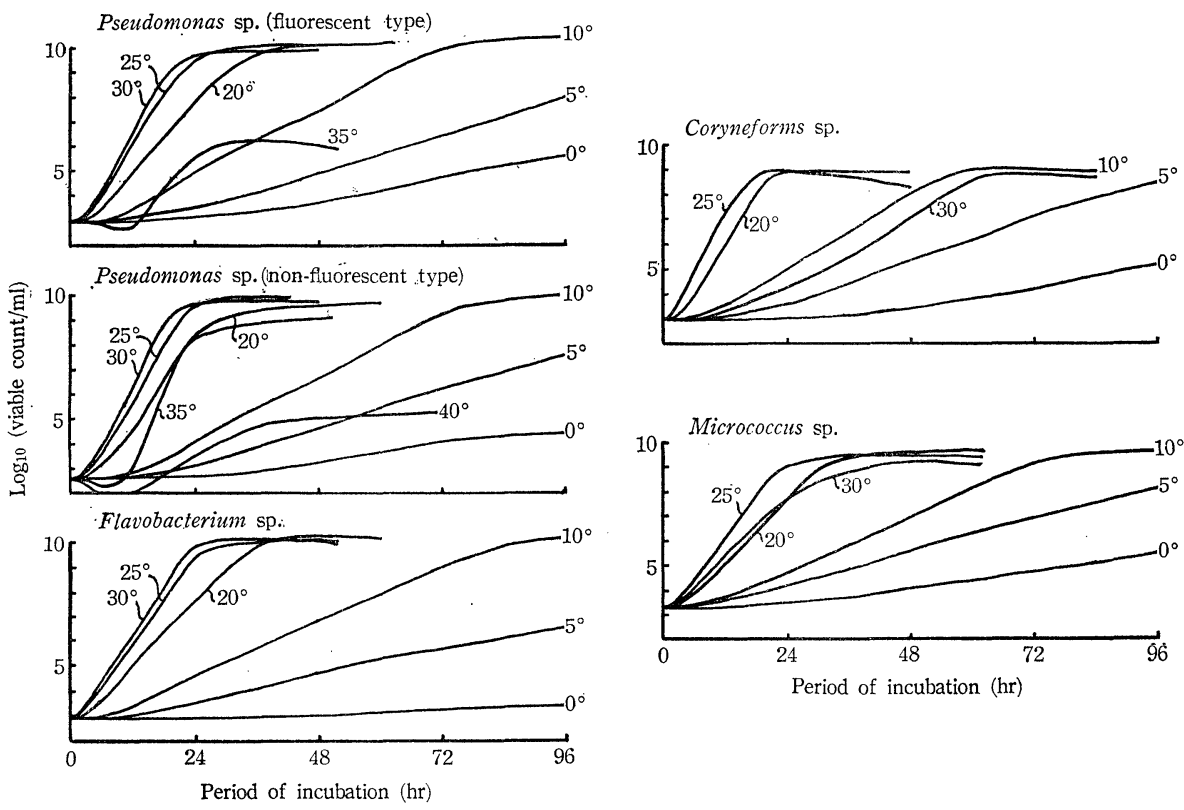

Fig. 1. The effect of incubation temperatures on the growth of the psychrotrophic isolates 


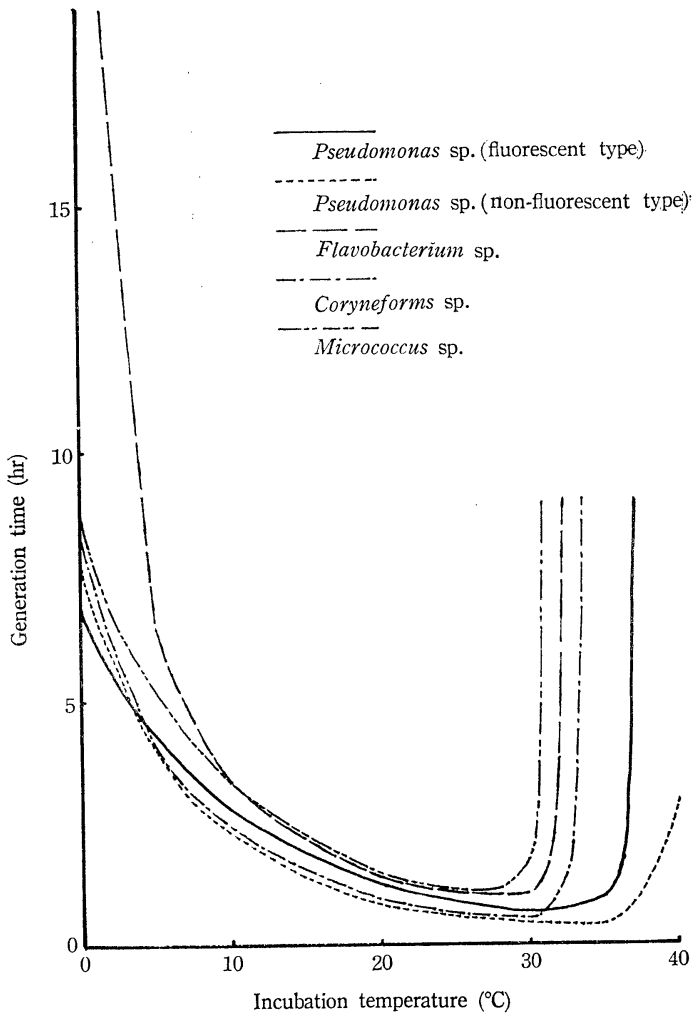

Fig. 2. Generation times of the psychrotrophic isolates at various incubation temperatures

る発育曲線を Fig. 1 に示す.

いずれの供試菌株も，0 30॰の間で発育が認められ， 25 たは $30^{\circ}$ で最も良好な発育を示した。 この両温度で の発育状態にあまり差はなかったが，概してグラム陽性 菌は25の方が良かった。 $35^{\circ}$ ではPseudomonas に属 する 4 菌株が発育し, その内, けい光のないPseudomonas は $40^{\circ}$ でも発育が認められたが，450ではいずれ の菌株も発育を示さなかった. なお， $35^{\circ}$ 以上での発育 状態は培養初期に比較的長い誘導期とその間の菌数値の 減少が観察され, 対数増殖期に入るとかなり急速に定常 期に移行した。 また，低温ほど誘導期が長くなる傾向が みられた。

定常期の菌数は一般にグラム陰性菌は培養液 $1 \mathrm{ml}$ 当 たり $10^{10}$ 個のオーダーに達したが，グラム陽性菌ではそ れより 1 オーダー程度低く, また, 培養液の混濁度もグ ラム陰性菌の方が高かった，定常期には $20 \sim 30^{\circ}$ では供 試菌株の多くがほぼ24時間以内に到達し，10では全菌 株とも72時間程度で定常期の菌数に達した。一方, 至適 発育温度より高い温度では定常期の菌数值が低くなる傾 向がみられ，なかでもけい光のある Pseudomonas の $35^{\circ}$ 培養执よびけい光のないPseudomonas の $40^{\circ}$ 培養
では至適発育温度に拈けるより 4 オーダー程度低く, し かも一般に早く死滅期に移行した。

菌属別の各こう配温度での発育を比較するために， Fig. 1 の菌株について0〜 40に护発育温度曲線を Fig. 2 に示す.

Pseudomonas に属する菌株は一般に他の菌属に比 較して低温での発育が良く，なかでもけい光のある Pseudomonas は $0^{\circ}$ での世代時間が 2 菌株とも 6 時間台 であった。しかし，他の菌属では Coryneforms と Micrococcus 各 1 株を除さいずれも $0^{\circ}$ での世代時間は

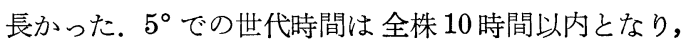
$10^{\circ}$ 以上になると, 培養温度による差は少なくなり, グ ラフのこら配も $10^{\circ} を$ 境にして明らかな差が認められ た.

以上のまとめとして，Table 1 に 各菌株の 最低，至 適，最高発育温度および世代時間を示す。

Table 1 から明らかなように，同一菌属といえども各 こう配温度における発育はかなり異なっていた。しか し, 全般的にみて Pseudomonas に属する菌株は他の 菌属のものに比べて幅広い発育温度域を示し, しかも, 各こう配温度で良好な発育を示した。

\section{2. 保存菌株の発育温度特性}

供試菌株のうち, Escherichia coli とStaphylococcus aureus は他の菌株とかなり異なる発育を示したので， この 2 菌株を除く 6 菌株の発育温度特性について, 凍結 豚肉分離菌株の場合之同様, Fig. 3 および 4 亿示す.

6 菌株中, Pseudomonas fluorescens, Pseudomonas fragi, Microbacterium thermosphactum, Micrococcus caseolyticus の 4 菌株は Table 1 に示すよう に，凍結豚肉分離菌株の発育にかなり類似していた が， $5^{\circ}$ 以下での発育は全般的に劣っていた。 そのらち Pseudomonas に属する 2 菌株は他の菌株に比べて発育 温度域も広く，低温での発育も良好であった。なお， $10^{\circ}$ では Microbacterium thermosphactum は全供試 菌株の中で最も発育が早く，世代時間は 111 分であり， ほぼ48時間で定常期に達した. しかし, Flavobacterium suaveolens は $0^{\circ}$ で発育せず，各こう配温度での発育も 他の菌株よりかなり劣り, 至適発育温度は $35^{\circ}$ であっ た。一方，Cytophaga は至適発育温度は $30^{\circ}$ であった が，発育温度域が $10 \sim 30^{\circ}$ と狭く，0，50では菌数が減少 し48時間目以後は測定されなかった。

Escherichia coli と Staphylococcus aureus の各 こう配温度における発育は凍結豚肉分離菌株のいずれと もかなり異なる傾向を示したので，凍結豚肉分離菌株の らちからけい光のあるPseudomonas sp.を1株選び， これら 3 菌株間の発育温度曲線の比較を Fig. 5 に示 †.

Escherichia coli と Staphylococcus aureus の発 育温度域は凍結豚肉分離菌株に比べて，上・下ともほぼ 
Table 1. Cardinal Growth Temperatures and Generation Times of the Test Strains

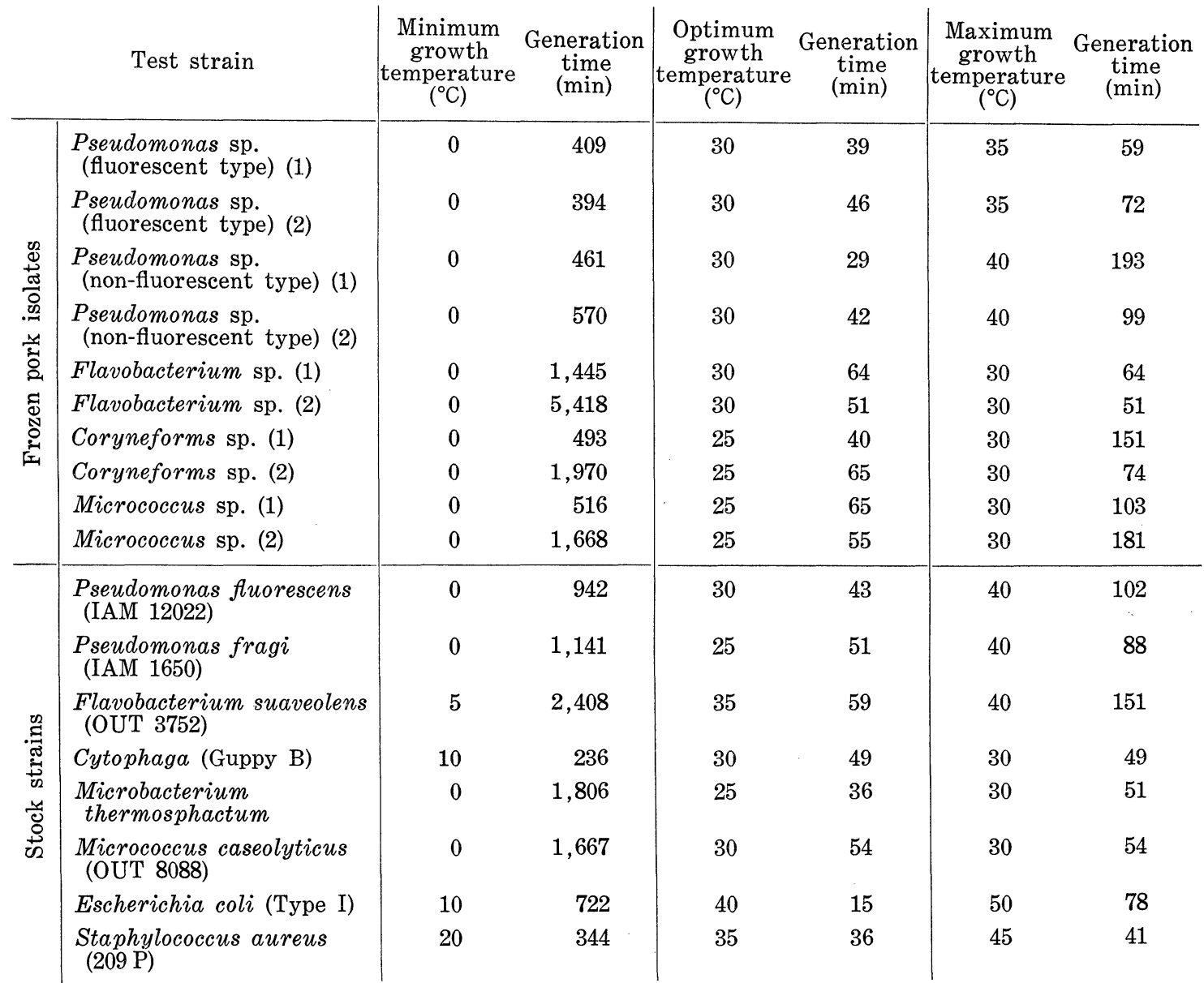

$10^{\circ}$ 前後中温部に片寄り, 至適発育温度も同様に高かっ た。また，培養温度の低下に伴ら発育速度の低下も顕著 であった. $20^{\circ}$ 以上では Escherichia coli は全供試菌 株中最も発育が良く, $40^{\circ}$ におけける世代時間が最も短く 約 15 分で, 他の菌株の 最短世代時間の $1 / 2$ 以下であっ た.しかし, Staphylococcus aureus の最短世代時間 は他の菌株のそれと大差なかった。

\section{考察}

低温で発育する細菌群に対しては，これまで好冷細菌 あるいは低温細菌と呼ばれるなどきわめて漠然とした概 念の下で取り扱われており，今日に至っても全面的に支 持を受けるような定義づけがなされていず，いまだに両 者ともかなり混乱した状況の下で取り扱われている．従 来, 至適発育温度, 最高, および最低発育温度などの 温域を明確にした上で，両者の概念を確立しょうとす る試みが数多くなされている。現段階では $\mathrm{Eddy}^{7}$ や Kandler ${ }^{8)}$ の提案と，さらにそれらを集約した1968年の 国際酪農連盟 (IDF) 主催の 低温発育細菌に関するセミ
ナーの提案到に基づいた psychrotroph (低温細菌) と いら用語が一般に支持され，特に発育適温が $20^{\circ}$ 以下の ものに限り psychrophile（好冷細菌）とすることが望 ましいとの考え方が支配的であり ${ }^{10), 11)}$ ，次第に両者の 概念が明確化されつつあると思われる。このような観点 に立って psychrotroph といら用語で表される一連の細 菌群について考えると, 今回供試した凍結豚肉分離菌株 のほとんどが上記の概念で規定されるカテゴリーに入る ものであり，また，その発育温度特性は $0,5^{\circ}$ のよな 低温でも発育可能とはいらものの, 至適発育温度は25 $30^{\circ}$ にあるものと考えられる。したがって現状では食肉 に分布する低温発育細菌の大部分は著者のこれまでの調 査結果 ${ }^{1,2)}$ からも, psychrotroph あるいは Kandler の いら ${ }^{8)}$ psychrotrophic mesophilics とみなしてよいと 思われる.

なお，著者の調查範囲でも Witter ${ }^{12)}$ の総説に 記載 されているように，20以下に至適発育温度を有すると される psychrophile の存在を認めるには至らなかっ 

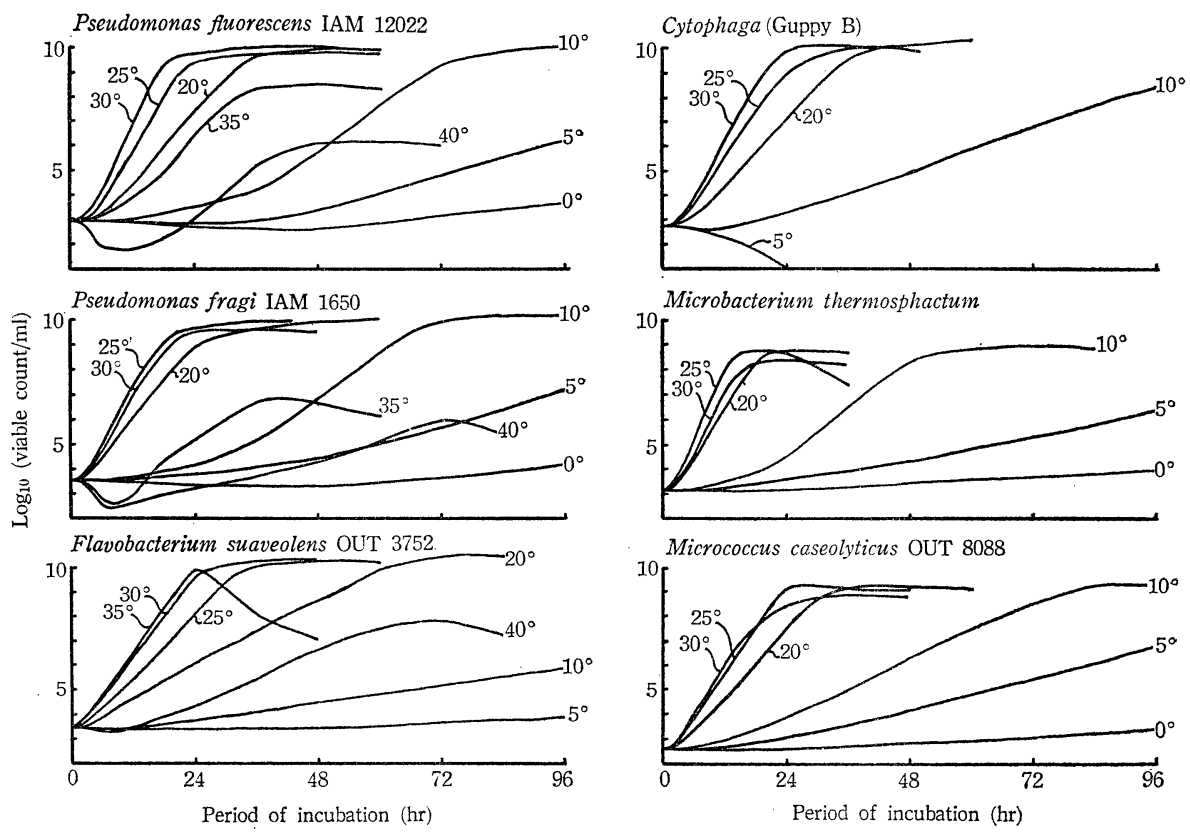

Fig. 3. The effect of incubation temperatures on the growth of six known strains

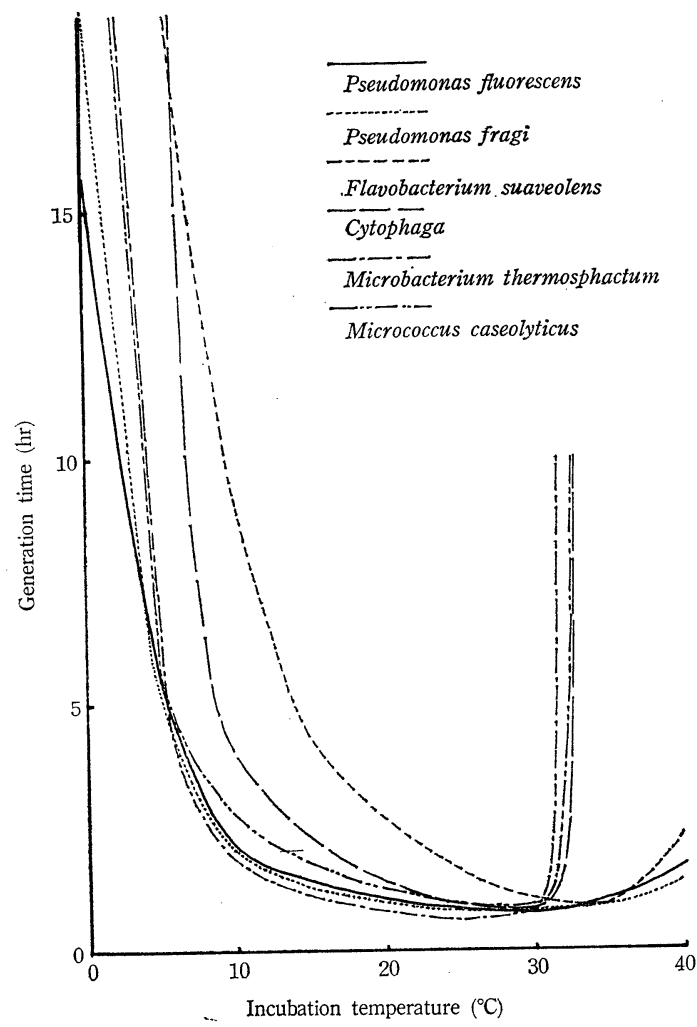

Fig. 4. Generation times of six known strains at various incubation temperatures
た。しかし，凍結豚肉分離菌株は従来から報告されてい $る^{13)}$ 19) 低温発育細菌の低温での発育と比較しても，培 養条件が異なるとはいえ，かなり良好な発育を示し，一 般に $0,5^{\circ}$ でも発育が可能であるところから， $0^{\circ}$ 前後の 低い温度域で貯蔵された食肉中でも十分増殖可能なこ とが推察され，品質管理上十分な配慮が必要である。一 方，比較のために用いた 8 保存菌株中，Pseudomonas fluorescens, Pseudomonas fragi, Microbacterium thermosphactum, Micrococcus caseolyticus の 4 菌 株は凍結豚肉分離菌株に近似した発育を示すところか ら，これらも凍結豚肉分離菌株同様 psychrotroph とみ なしてよいであろう。

低温発育細菌と考兄られるこれらの菌株は培養温度の 低下に伴い，漸次発育に要する時間が延長し， $5 \sim 10^{\circ}$ を 境にして顕著な発育速度の低下を示した。このような現

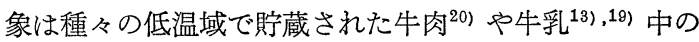
生菌数の消長で山観察されて扮り, 前報2 の分離菌株の 発育温度も 5 と $10^{\circ}$ では発育率に明らかな差がみられ た．以上のことから低温発育細菌には 5 と $10^{\circ}$ の間を境 にして環境温度に対する感受性が異なる臨界温度ともい らべきものが存在するものと考光られる.

供試菌株中，Pseudomonas に属する菌株は全般的に みて，他の菌属より低温での発育能力が高かったが，本 菌属以外は同一菌属でも温度の低下に伴、発育を異にし た。この事実は食肉を低温貯蔵した場合，本菌属が最終 的には污染菌叢の主体を占めることになる事実 ${ }^{1,3)}$ を裏 書きする理由の一つになるるのと思われる。 


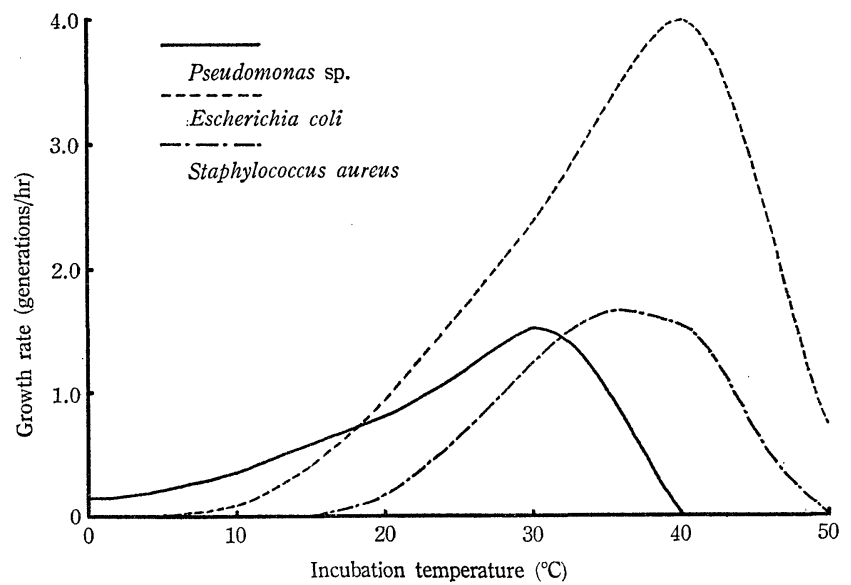

Fig. 5. Growth rates of Pseudomonas sp., Escherichia coli and Staphylococcus aureus at various incubation temperatures

これらの低温発育細菌といわゆる中温細菌とみなさ れている Escherichia coli および Staphylococcus aureus の発育温度特性とを比較すると, 低温発育細菌 では至適発育温度が $10^{\circ}$ 前後低く, 発育温度域も中温域 に及ぶとはいえ，概して低温部に片よる傾向がみられ， 培養温度の低下に伴ら影響も少なかった。これらの結果 は Brown $^{15)}$ や Ingraham ${ }^{16)}$ の報告とも一致するとこ ろから，両者の間には発育温度の点で明らかな差がある と考えられる. したがって, 従来から生菌数の測定条件 として実施されてきた中温細菌を対象とした $35 \sim 37^{\circ}$ 培 養の場合には低温発育細菌の発育がみられない場合があ り，実際よりも測定値が低く判定される傾向にある．特 に食肉の品質管理上の指標としての生菌数は污染細菌の かなりの部分が低温発育細菌と考えられることから，そ の測定条件としては低温発育細菌でも発育可能な温度 で，しかも成績判定の時間も比較的短くてすむ $25 \sim 30^{\circ}$ 培養が適当であろらと考えられる.

微生物の発育温度特性を知るために, 中江 ${ }^{21)}$ は定常熱 伝導系を応用した温度こう配培養法を開発し, 各種畜産 食品由来の低温発育細菌について検討し，この方法が優 れていることを報告した.この方法は寒天培地中の集落 の発現状況を観察し, それによって当該菌の温度特性を 知る目的からすれば良い方法である。しかし, 食品保蔵 の立場からみれば, 污染細菌の誘導期の長さ, 対数増殖 期に和ける発育速度ならびに菌体量などが重要な意味を 有すると考えられるので，これらに関する正確な情報を 種々の温度で同時に知るためには，そのつど菌数測定と いら多少の煩雑さはあるにしても, 著者が今回採用した 振とら培養を加味する温度こう配培養法の方がより優れ ていると考光る.すでに当研究所の丸山 ${ }^{22)}$ は Yersinia enterocolitica などの腸管系病原細菌について検討し成 果を得ている。この方法は発育温度特性のみでなく，他
の生理学的活性に及ぼす温度の影響なども知ることがで き, 将来, 低温発育細菌などを含めた食品污染細菌の挙 動を知る上からも有力な手段になるものと考えられる.

\section{要 約}

食肉を污染する低温発育細菌の発育温度特性を知る目 的で, 凍結豚肉から分離したけい光のあるPseudomonas, けい光のないPseudomonas, Flavobacterium, Coryneforms, Micrococcus の各 2 株と保存菌株の低 温発育細菌 6 株, 中温細菌 2 株について, 振とら温度こ ら配培養装置を用いて 0 から $5^{\circ}$ 間隔で $50^{\circ}$ まの各温度 に拈ける発育状態を比較した結果, 次の成績を得た。

1）分離菌株はいずれも $0^{\circ}$ で96時間以内に発育を示し た。

2）分離菌株の中で最高発育温度に差がみられ，けい 光のないPseudomonas は40, けい光のあるPseudomonas は35，その他の菌属は30であった。

3）分離菌株の至適発育温度は 25 たは $30^{\circ}$ で，その 温度での世代時間は29～65分であった。

4) $0^{\circ}$ に拈いて分離菌株中のPseudomonas の発育 は速やかで，これに比べて保存菌株の発育はかなり遅か った.

稿を終わるに臨み本研究に対し終始御指導を賜った当 研究所生活科学部長春田三佐夫博士ならびに本実験に当 たり有益なる御助言をいただいた微生物部丸山務研究員 に深甚なる謝意を表し，併せて梅木富士郎主任研究員に 感謝する。

本報告の概要は日本食品衛生学会第26回学術講演会で 報告した。

文 献

1）小久保弥太郎, 梅木富士郎, 春田三佐夫：食衛 誌. 12, 164 (1971).

2）小久保弥太郎： 東獣畜誌。 $19 \cdot 20$ 合併号, 184 
(1973).

3) 小久保弥太郎： 食衛誌。14，448 (1973).

4) Oppenheimer, C.H., Drost-Hansen, W.: J. Bact., 80, 21 (1960).

5) Vanderzant, C., Nickelson, R.: J. Milk and Food Tech., 32, 357 (1969).

6) Topley, W. W. C., Wilson, G.S.: "Principles of Bacteriology and Immunity" Vol. 1, p. 97 (1957) Arnold \& Co., London.

7) Eddy, B. P.: J. appl. Bact., 23, 189 (1960).

8) Kandler, O.: Milchwissenschaft, 21, 257 (1966).

9) Intern. Dairy Federat.: IDF VI-DOC-48 (1969).

10）中江利孝：乳技協資料， 20，2 (1970).

11）矢野信礼：“食品衛生の微生物” p. 142 (1970) 朝倉書店。
12) Witter, L. D.: J. Dairy Sci., 44, 983 (1961).

13) Greene, V. W., Jezeski, J. J.: Appl. Microbiol., 2, 110 (1954).

14) Vanderzant, W.C., Moore, A. V.: J. Dairy Sci., 38, 743 (1955).

15) Brown, A.D.: J. gen. Microbiol., 17, 640 (1957).

16) Ingraham, J. L.: J. Bact., 76, 75 (1958).

17) Sinclair, N. A., Stokes, J. L.: ibid., 85, 164 (1963).

18) Olsen, R. H., Jezeski, J. J.: ibid., 86, 429 (1963).

19）小川益男：東京農工大学学術報告， $11 ， 71$ (1968).

20) Ayres, J. C.: Food Res., 25, 1 (1960).

21) 中江利孝: 農化. 42, 639 (1968).

22）丸山 務：日細誌。28，343 (1973). 